\title{
The Effect Bonapace Method Reduces Labor Pain Of Active Phase I To Intranatal Care
}

\author{
Luluk Susiloningtyas, Ratna Feti Wulandari \\ STIKES Pamenang, Kediri, Indonesia \\ luluksusiloningtyas@gmail.com
}

\begin{abstract}
The Pain is an inseparable component of labor. The labor pain occurs due to nerve receptor stimuli followed by uterine muscle contractions and is accepted in the lumbosacral region, hips and intestines. During the process of opening the cervix must be accompanied by labor pain. Pain is a physiological process during labor but can cause problems that cannot be resolved properly. The problems pain aren't implementation can be stress intra natal that can stimulate secretion catecholamines. The catecholamines secretion will cause inadequate uterine contractions intranatal, the fetus is risk fetal distress due to decreased utero placental perfusion. Labor pain is also one of the things makes uncomfortable intra natal. The level of pain felt to intranatal can be alleviated by a variety actions. One non-pharmacological method for reduces labor painis the Bonapace method. The Bonapace Method is an alternative method for dealing with labor pain, involving the husband or family intranatal. This method combines several nonpharmacological techniques, namely relaxation, massage, acupressure and family assistance, so can be effective management pain labor care. This purpose study was effect bonapace method reduces labor pain of active phase I to intranatal care in PMB Lilik Ernawati, S.ST Selosari Village, Kandat District, Kediri Regency in 2020. The type of research used was Quasi Experimental by using cross sectional, looking for one group pretest research. posttest design. The sampling technique was Accidental Sampling. The independent variable was the Bonapace Method, the instrument used was a checklist. Dependent variable was the storage of labor pain in the active phase I, the instrument used to measure the level of pre and post pain with an observation sheet with a pain scale between 0 to 10 and an interview using the Verbal Desuctive Scale (VDS), scale, value $0=$ no injury , 1-3 = mild illness, 4-6 = moderate illness, 7-9 = severe illness, $10=$ very severe illness. Analysis of data using the Wilcoxon Sign Rank. The results data analysis stated that $\operatorname{sig}(\mathrm{p})=0,000$ where $\alpha=0.05, \mathrm{p} \& \mathrm{lt} ; \alpha$, means that there was support for the Bonapace Method for the protection of the first stage of labor in the active phase of the mother during child birth during Correlation or using the Wilcoxon Correlation $=-0.382$.
\end{abstract}

Key Words: Bonapace Method, Labor, Reduces pain

Received December, 25, 2019; Revised January 24, 2020; Accepted February 15, 2020 


\section{STRADA Jurnal Ilmiah Kesehatan}

DOI: $10.30994 /$ sjik.v9i1.281

ISSN: 2252-3847 (print); 2614-350X (online)

Vol.9 No.1. May 2020. Page.248-257

\section{INTRODUCTION}

During the process of opening the cervix must be accompanied by labor pain. Pain is an inseparable component of labor. Labor pain occurs due to nerve receptor stimuli followed by uterine muscle contractions and is felt in the lumbosacral region, hips and intestines. Labor pain can cause stress which causes excessive release of hormones such as catecholamines and steroids. This increase in hormones can cause metabolic and hemodynamic changes that are worse in labor, can cause tension in smooth muscles and blood vessels, resulting in decreased uterine contractions and uteroplasenter circulation, reduced blood flow and oxygen to the uterus and the emergence of uterine ischemia which makes the pain impulses increase ${ }^{1}$.

Pain is a physiological process during labor but can also cause problems if it is not treated properly. Some of the problems that can arise if pain is not treated is stress in the mother which can stimulate the secretion of catecholamines. As a result of catecholamine secretion will cause inadequate uterine contractions, the fetus is at risk of fetal distress due to decreased uteroplacental perfusion. In addition labor pain is an unpleasant stimulus that causes fear and worry. This situation will stimulate an increase in catecholamines which can cause interference with the strength of uterine contractions so that uterine insertion occurs if not corrected, which will cause prolonged labor ${ }^{2}$.

Pain is defined as an unpleasant sensory and emotional experience associated with actual or potential tissue damage consisting of at least two components supported by an independent neurophysiological pathway namely a descriptive sensory component (intensity) and the second component is effective motivation (discomfort) which can be selectively in modulation. Although the intensity of pain felt by women during childbirth is usually not related to tissue damage, previous studies have noted labor pain as one of the most severe forms of pain ever recorded using the McGill Pain Questionnaire or the Visual Analog scale (VAS) ${ }^{1}$

There are several techniques to reduce labor pain, namely pharmacological and nonpharmacological. Pharmacological approaches are directed at eliminating physical sensations in labor pain. While non pharmacology is directed to prevent suffering. In the world survey, the experience of women during childbirth is found to be $69 \%$ given at least one nonpharmacological method, while $70 \%$ of women use epidural analgesia 3 . In addition, thousands of cesarean surgeries are planned and effective every year for fear of illness, especially nulliparous women. Childbirth causes an increase in epinephrine and norepinephrine, flat pressure and heart rate, oxygen consumption for the mother and beta endorphins. In addition vasoconstriction due to catecholamines causes a decrease in uterine blood flow and this can cause increased dystocia and decreased neonatal APGAR ${ }^{4}$.

Currently developed by the health care unit is to reduce pain during labor by providing non-pharmacological methods with implementation without side effects, building selfconfidence and participation of maternity mothers. Therefore as a midwife must provide care dear mother, one of which is a reduction in pain. One non-pharmacological method is the Bonapace Method. The Bonapace Method is an alternative method for dealing with labor pain, involving the husband or family of the mother in labor. This method combines several nonfatmacological techniques, namely relaxation, massage, acupressure and family assistance. This method uses several pain management techniques to control pain based on three neurophysiological pain modulation models, first controlling the central nervous system through breathing, relaxation and cognitive regulation, second using the stimulus, third 


\section{STRADA Jurnal Ilmiah Kesehatan}

DOI: $10.30994 /$ sjik.v9i1.281

ISSN: 2252-3847 (print); 2614-350X (online)

decreasing the inhibition by the strongest acupressure hyperstimulation. Thus, this bonapace method is considered effective in the treatment of labor pain ${ }^{4}$.

The observation results in carrying out childbirth care in helping to reduce pain in intranatal care, it can be seen that the bonapace method was still in the stage of intervening or controlling the central nervous system only by means of breathing techniques only, not yet doing light relaxation on the back during contractions and administration of hyperstimulation analgesics during contractions. The step of giving analgesic hyperstimulation can do by assisting childbirth to make the second cause of pain by massage with a strong emphasis on the trigger point, namely the lower back, then alternating with the points on the hands and buttocks, until the patient can choose which points are felt to be most contributing to the reduction in labor pain. Bonapace method is one of the non-pharmacological methods that is effective in helping mothers in reducing pain. Because necessary it was done pain reduction methods with the right Bonapace method so that it can help intranatal reducing pain during labor so as to facilitate labor.

Based on the description above, the researcher was interested in conducting research with the title the effect bonapace method reduces labor pain of active phase I to intranatal carein PMB LilikErnawati, Selosari Village, Kandat District, Kediri Regency, which hopes to reduce pain, increase the comfort and calm intranatal.

\section{METHODS}

\section{Design}

The research design used this study was Quasi Experimental with cross sectional approach. The research design used was one group pretest-posttest design.

\section{Research variable}

The research variables observed included the independent variable, the Bonapace Method. The dependent variable was Reduction of Stage I Active Labor pain in the laboring intranatal.

\section{Research Subjects}

The population was all intranatalin the first phase of active phase in PMB Lilik Ernawati, Selosari Village, Kandat District, Kediri Regency. The research sample was part of intranatal in PMB LilikErnawati, Selosari Village, Kandat District, Kediri Regency from January to April 2020, sampling technique used accidental sampling so that a sample of 20 respondents was included in the inclusion criteria including mothers willing to be respondents and first-time mothers giving birth Active phase The exclusion criteria for this study include maternity women with emergency situations (referral).

\section{Provision of the Bonapace Method}

The Bonapace Method was an alternative method for dealing with labor pain, involving the husband or family of the mother in labor. This method combines several non-fatmacological techniques, namely relaxation, massage, acupressure and family assistance. This method uses several pain management techniques to control pain based on three neurophysiological pain modulation models, first controlling the central nervous system through breathing, relaxation and cognitive regulation, second using the stimulus, third decreasing the inhibition by the strongest acupressure hyperstimulation. Action Bonapace method with the Cecklish Instrument

\section{Reduction of labor pain}

Labor pain painwas felt by the mother during labor in the first phase of active phase labor. Assessed by observation using the pain scale.Called a reduction in pain if there was a decrease 
in criteria before and after the Bonapace Method was given. Reduction of labor pain in the active phase I, the instrument used to measure the level of pre and post pain with an observation sheet with a pain scale between 0 to 10 and an interview using the Verbal Descriptive Scale (VDS), rating scale, value $0=$ no pain, $1-3=$ mild pain, $4-6=$ moderate pain, $7-9=$ severe pain, $10=$ very severe pain.

Measurement of the percentage of labor pain before Bonapace Method was given to the first stage of labor in the active phase

Childbirth pain in the first-phase active intranatal can be known from observations with pain scale before the respondent was given Bonapace Method then the data was processed so that a percentage appears stating the percentage of labor pain criteria. While labor pain after giving the Bonapace Method can known from the observation of labor pain after giving the Bonapace Method with pain scale for respondents conducted in PMB Lilik Ernawati Selosari Village, Kandat District, Kediri Regency, then was compared with pain before the Bonapace Method.

\section{Statistic analysis}

Bivariate analysis was used to determine the effect between independent variables and dependent variables. Data were analyzed using the Wilcoxon Sign Rank test. To determine whether there was an influence between the independent variable and the dependent variable, then using the $p$ value compared to the error rate used is $5 \%$ or 0.05 . If $p$ value $\leq 0.05$, then Ho was rejected, which means there was a significant influence between the independent variable and the dependent variable. While the level of correlation uses Wilcoxon correlation.

\section{RESULTS AND DISCUSSION}

The percentage of maternal pain during the first phase of active labor before being given the Bonapace Method:

Table 1. Labor pain during first phase of active labor before giving Bonapace Method

\begin{tabular}{|c|l|c|c|}
\hline No & Labor Pain Criteria & Frequency & Percentage (\%) \\
\hline 1 & No pain & 0 & 0 \\
\hline 2 & Mild Pain & 0 & 0 \\
\hline 3 & Moderate Pain & 0 & 0 \\
\hline 4 & Severe pain & 15 & 75 \\
\hline 5 & Very Pain & 5 & 25 \\
\hline \multicolumn{2}{|c|}{ Total } & 20 & 100,00 \\
\hline
\end{tabular}

Based on the results of research conducted in PMB Lilik Ernawati, Selosari Village, Kandat District, Kediri Regency on January 2 - April 23, 2019 before giving hydrotherapy from 20 respondents, it can be seen that those who experience severe labor pain were 15 respondents $(75 \%)$ while some respondents namely as many as 5 respondents $(25 \%)$ have very severe pain criteria

According to some experts, the pain that occurs in labor due to real tissue damage. Pain perception was very individual, much influenced by physiological, pathological, emotional factors. psychological, cognitive, environmental and social (Bonapace, 2013). Labor pain can 


\section{STRADA Jurnal Ilmiah Kesehatan}

DOI: $10.30994 /$ sjik.v9i1.281

ISSN: 2252-3847 (print); 2614-350X (online)

cause stress which causes excessive release of hormones such as catecholamines and steroids. This increase in hormones can cause metabolic and hemodynamic changes that are worse in labor. In addition, it can cause tension in smooth muscle and blood vessels, resulting in decreased uterine contractions and uteroplasenter circulation, reduced blood flow and oxygen to the uterus and the emergence of uterine ischemia that makes the pain impulses more numerous (Sumarah, 2009)

The delivery process was associated with discomfort alwaysor pain during the delivery process. Pain that occurs during labor was caused by cervical stretching, uterine contractions and fetal decline that causes prostaglandin to be released which can cause pain. Pain that was not resolved can pose a physiological and psychological danger to the mother and fetus.

A related study was conducted by Afni (2018) that some mothers who gave birth felt severe pain, only $9-14 \%$ of women gave birth to experience mild pain without reducing labor pain. Baker (2001) in Utami (2018), explained the results of a study conducted in the UK, of women who gave birth, found that $93.5 \%$ felt severe pain or unbearable pain. The results of other studies that support is Pratiwi (2015), found only 15\% of deliveries that took place without pain or mild pain, $35 \%$ of deliveries accompanied by moderate pain, $30 \%$ of deliveries accompanied by severe pain and $20 \%$ of deliveries accompanied by extreme pain.

In accordance with the theory put forward by Deasyana (2015), that the peak of pain occurs at the end of the first stage, which was the active phase where the opening becomes complete, reaching 10. Along with increased opening, the pain and contractions become stronger, the pain comes from uterine contractions, so the contractions become more flexible, longer and stronger so that the pain felt more intense.

Thus it was expected that all mothers who will face childbirth always routinely conduct Antenatal Care visits. This was so that every mother can receive information provided by health workers, including preparation for mothers in the face of childbirth later. So that every mother who will give birth can have a picture of what will be experienced, including pain in childbirth.

The percentage of intranatal pain during the first phase of active labor after the Bonapace Method was given:

Table 2. Maternal pain during the active phase after administration of the Bonapace Method

\begin{tabular}{|c|l|c|c|}
\hline No & Labor Pain Criteria & Frequency & Percentage (\%) \\
\hline 1 & No pain & 0 & 0 \\
\hline 2 & Mild Pain & 2 & 10 \\
\hline 3 & Moderate Pain & 15 & 75 \\
\hline 4 & Severe pain & 3 & 15 \\
\hline 5 & Very Pain & 0 & 0 \\
\hline \multicolumn{2}{|l|}{ Total } & 20 & 100,00 \\
\hline
\end{tabular}

Based on the results of the study showed that labor pain in the first stage of labor for women active during delivery after gotBonapace Method was mostly on the criteria of being as many as 15 respondents (75\%), and partly of 2 respondents $(10 \%)$ have criteria of mild pain and partly again as many as 3 respondents $(15 \%)$ have severe pain criteria. 


\section{STRADA Jurnal Ilmiah Kesehatan}

DOI: $10.30994 /$ sjik.v9i1.281

The Bonapace Method was an alternative method for dealing with labor pain, involving the husband or family of the mother in labor. This method combines several nonpharmacological techniques, namely relaxation, massage, acupressure and family assistance. This method was uses several pain management techniques to control pain based on three neurophysiological pain modulation models, first controlling the central nervous system through breathing, relaxation and cognitive regulation, second using the stimulus, third decreasing the inhibition by the strongest acupressure hyperstimulation. Thus, this bonapace method was considered effective in the treatment of labor pain ${ }^{4}$.

Several studies that used the Bonapace Method in labor have proven that the Bonapace Method can reduce the used of tools in labor and did not require a long time in women with dystocic labor. Bonapace method was a technique that can be chosen to reduce pain, increase relaxation and comfort of maternity so that this bonapace method was considered effective in handling labor pain ${ }^{4}$.

Based on an assessment of research results relating to the administration of the Bonapace Method in reducing labor pain. The Bonapace Method was the right course of action to relieve pain in some women. The effectiveness of the bonapace method was assessed more for maternity pain due to a combination of several non-pharmacological techniques ${ }^{1}$.

The Bonapace Method was one of the non-pharmacological methods that was implemented without any side effects, can build self-confidence, and participation from patients so that it was expected to reduce the level of referral ${ }^{1}$. Mechanism Bonapace Method, starting from the principle that the brain cannot focus pain in two places at once. Creating secondary pain with a strong emphasis on labor contractions will help the body release endorphins (a kind of natural morphine) which will help relieve pain from contractions. So, this bonapace method was considered effective in handling labor pain ${ }^{1}$. This bonapace method technique starts with the intervention or control of the central nervous system, intervention or control of the central nervous system was done by means of respiratory techniques. Relaxation during labor affects the psychological and work systems of the brain in controlling labor pain. Besides relaxing light massage on the back during contractions, massage or emphasis on certain parts of the body was considered to describe a stimulus that can interfere with the transmission of pain to the brain, which is effectively able to close the gate for pain reception, which also stimulates the release of endorphins and increased levels of serotonin, to inhibit the transmission of nerve signals dangerous to the brain. In addition, the administration of hyperstimulation analgesics during contractions, hyperstimulation analgesics during contractions done by assisting childbirth to make the second cause of pain (by massage with a strong emphasis) at the trigger point, namely the lower back, then alternating with the points in the hand and in the buttocks, until the patient can choose which points were felt to contribute most to the reduction in labor pain. Family assistance during childbirth can also affect the psychological and brain work systems in controlling labor pain ${ }^{1}$

Various methods have been introduced to intranatal in dealing with labor pain, both pharmacologically and non pharmacologically. Pharmacological methods were more expensive and potentially have adverse effects, while non-pharmacological methods were cheaper and more effective and have no side effects. Some nonpharmacological methods that are often performed include relaxation, breathing techniques, movement and position changes, massage, hydrotherapy, heat / cold therapy, music therapy, acupressure and aromatherapy (Handerson, 2009). 


\section{STRADA Jurnal Ilmiah Kesehatan}

DOI: $10.30994 /$ sjik.v9i1.281

ISSN: 2252-3847 (print); 2614-350X (online)

For this reason, it was expected that health workers especially midwives and families can help reduce the discomfort of labor pain experienced by intranatalby reducing labor pain with non-pharmacological techniques, one of which was by giving Bonapace Method

The Influence of the Bonapace Method on the Reduction of First Stage Active Labor Pain in PMB LilikErnawati, Selosari Village, Kandat District, Kediri Regency in 2020 was illustrated in the following table:

Table 3. Cross Tabulation The Effect Bonapace Method Reduces Labor Pain Of Active Phase I To Intranatal Carein PMB LilikErnawati, Selosari Village, Kandat District, Kediri Regency in 2020

\begin{tabular}{|c|c|c|c|c|c|c|c|c|c|c|c|c|}
\hline \multirow{2}{*}{\multicolumn{3}{|c|}{$\begin{array}{l}\text { Criteria for Labor Pain Before } \\
\text { Giving the Bonapace Method }\end{array}$}} & \multicolumn{10}{|c|}{$\begin{array}{l}\text { Criteria for Labor Pain After Giving the } \\
\text { Bonapace Method }\end{array}$} \\
\hline & & & \multicolumn{2}{|c|}{ No pain } & \multicolumn{4}{|c|}{ Mild Pain $\begin{array}{l}\text { Moderate } \\
\text { Pain }\end{array}$} & \multicolumn{2}{|c|}{$\begin{array}{l}\text { Severe } \\
\text { pain }\end{array}$} & \multicolumn{2}{|c|}{ Very Pain } \\
\hline & $\sum$ & $\%$ & $\sum$ & $\%$ & $\sum$ & $\%$ & $\sum$ & $\%$ & $\sum$ & $\%$ & $\sum$ & $\%$ \\
\hline No pain & 0 & 0 & 0 & 0 & 0 & 0 & 0 & 0 & 0 & 0 & 0 & 0 \\
\hline Mild Pain & 0 & 0 & 0 & 0 & 0 & 0 & 0 & 0 & 0 & 0 & 0 & 0 \\
\hline Modera & 0 & 0 & 0 & 0 & 0 & 0 & 0 & 0 & 0 & 0 & 0 & 0 \\
\hline Severe pain & 15 & 75 & 0 & 0 & 2 & 10 & 11 & 55 & 3 & 15 & 0 & 0 \\
\hline Very Pain & 5 & 25 & 0 & 0 & 0 & 0 & 4 & 20 & 0 & 0 & 0 & 0 \\
\hline Total & 20 & 100 & 0 & 0 & 2 & 10 & 15 & 75 & 3 & 15 & 0 & 0 \\
\hline
\end{tabular}

Based on the table above showed that respondent data The Influence of Bonapace Method Against Reduction of First Stage of Labor Pain Active Phase of Maternity Women in PMB Lilik Ernawati Selosari Village Kandat District Kediri District respondents (75\%) and 5 respondents (25\%) experienced very severe pain criteria. After being given the Bonapace Method, there was a reduction in pain, namely respondents who experienced severe pain before being given the Bonapace Method, a decrease of 15 respondents mostly experienced moderate pain, namely 11 respondents $(55 \%)$, criteria for severe pain as many as 3 respondents $(15 \%)$

The results of the statistical test of the research on the Effect of the Bonapace Method on the Reduction of First Stage Active Labor Pain in PMB Lilik Ernawati, Selosari Village, Kandat District, Kediri Regency in 2020 were followed:

Wilcoxon correlation calculation results can see in the appendix Statistics Test b

\begin{tabular}{|l|cr|}
\hline & \multicolumn{2}{|c|}{$\begin{array}{c}\text { Pain after the Bonapace Method } \\
\text { (deselerasi) }\end{array}$} \\
& $\begin{array}{c}- \\
\text { Pain Before the Bonapace Method } \\
\text { (deselerasi) }\end{array}$ \\
\hline $\begin{array}{l}\text { Z } \\
\text { Asymp.Sig. }\end{array}$ & $-3,852 \mathrm{a}$ \\
(2- tailed) & 000 \\
\hline
\end{tabular}

a. Based on positiverank

b. Wilcoxon Signed RankTest 
STRADA Jurnal Ilmiah Kesehatan

DOI: $10.30994 /$ sjik.v9i1.281

ISSN: 2252-3847 (print); 2614-350X (online)

Vol.9 No.1. May 2020. Page.248-257

The results of calculations did to computer software using the Wilcoxon Correlation formula obtained $\rho$ value $=0,000$ thus $\rho<\alpha$ then (H1) was accepted and (H0) was rejected, meaning that there was an influence between the Bonapace Method on reducing labor pain when I Active Phase. With a Wilcoxon Correlation value of - 3, 852

Based on the results of statistical tests it can be concluded that there are differences in pain before and after the Bonapace Method was given with a value of $\mathrm{P}=0,000$. The results obtained showed that there was a decrease in labor pain scale after being given the Bonapace Method of labor pain before and after being given the Bonapace Method. The decrease in pain scale caused by creating secondary pain with a strong emphasis on labor contractions will help the body release endorphins (a kind of natural morphine) which will help relieve pain from contractions. This shows a significant reduction in pain compared to those didn't use

This was accordance with Nasriyah's research (2014) which examines the Application of the Bonapace Method for labor pain between conventional methods and the bonapace method, which states that the Bonapace Method was more effective in reducing labor pain. The results showed, the statistical test results with the Wilcoxon test in the control group obtained a synificancy value of 0.083 ( $>>0.05)$ there was no significant difference between before and after the administration of conventional methods, whereas in the treatment group (Bonapace method) the statistical test with test Wilcoxon obtained a significance value of $0,000(p>0.05)$, there was a significant difference between before and after the administration of the Bonapace method to decrease labor pain. The Bonapace Method can reduce pain significantly ${ }^{14}$

This was line with the research of Bonapace et al. (2013) who assessed the effect of the Bonapace method compared to traditional labor training methods (TCTPs), the results showed a positive correlation between treatment with pain (pain intensity: $\mathrm{P}, 0.01$; pain discomfort: $\mathrm{P}$, 0, 01). When compared with TCTP, the Bonapace method showed a significantly lower overall pain perception for both intensity $(45 \%, \mathrm{P}, 0.01)$ and discomfort $(46 \%, \mathrm{P}, 0.01) 15$. This was also in accordance with the study. This was also accordance with research conducted by Nurul, Fania. (2014) entitled the Bonapace Method for labor pain which showed that the administration of the Bonapace Method was very effective in reducing labor pain ${ }^{2}$.

The results also showed that mothers with severe pain as much as 3 respondents after being given the Bonapace method were still experiencing severe pain. This showed that labor pain may also be influenced by other factors. Factors affecting labor pain include the age of very young women and elderly mothers complaining of higher labor pain levels, primiparas experienced greater pain at the beginning of labor, whereas multiparas experienced an increase in pain levels after labor with a rapid decrease in the second stage of labor., intranatalwho have small pelvis, large babies, babies with abnormal presentations, mothers who have a history of dysmenorrhoea can experience increased pain perception, possibly due to excess prostaglandin production, anxiety will increase individual response to pain, unpreparedness to undergo childbirth, support and companions for labor and social and cultural factors ${ }^{16}$.

Therefore, as health workers, especially midwives and families to be able to helped reduce labor pain experienced by mothers in various ways, including one by non-pharmacological ways, one of which is by providing Bonapace Method which has been proven effective in reducing labor pain in mothers so that labor can proceed safely and smoothly. 


\section{STRADA Jurnal Ilmiah Kesehatan}

DOI: $10.30994 /$ sjik.v9i1.281

ISSN: 2252-3847 (print); 2614-350X (online)

Vol.9 No.1. May 2020. Page.248-257

\section{CONCLUSIONS}

Conclusions Administration of the Bonapace Method can influence the reduction of labor pain in the active phase I. It is recommended that the Bonapace Method be used as an alternative to reduce maternal pain in first phase active mothers.

Suggestions There should be further research on the administration of the Bonapace Method to the labor process in the first stage and other factors that influence labor pain in the active phase.

Suggestions from researchers for research sites are for Research Sites to increase the role of health workers in the delivery room to better understand and apply non-farnakologi techniques such as the Bonapace Method, while respondents are expected to provide information to maternity mothers and families about appropriate pain reduction methods safe and effective non pharmacology to reduce pain in labor so that it can provide comfort to the mother in the first phase of the Active phase.

\section{REFERENCE}

1. Bonapace J, Chaillet N, Gaumond I, Savoie E, Marchand S. Evaluation of the Bonapace Method : a spesific educational intervention to reduce pain during childbirth. J Pain Res. $2013 ; 6: 653-66$

2. Nurul, Fania. (2014). Metode Bonapace Untuk Penurunan Nyeri Persalinan. Prodi Magister Kebidanan. Fakultas Kedokteran Universitas Padjajaran. Bandung. 5-7 September 2014. ISSN : $2406-8934$

3. Ratnaningsih, M.D. (2010). Perbedaan Tingkat Nyeri Pada Ibu Bersalin Primipara Kala 1 Fase Aktif sebelum dan Setelah di Berikan Kompres Panas Kering (Buli-Buli Panas) di Rumah Bersalin Siti Khodijah Kabupaten Tegal. Semarang: Universitas Muhammadiyah Semarang.

4. Shafaie FS, Kazemzadeh R, Amani F, Heshmat R. The Effec of Acupressure on Sanyinjio and Hugo Points on Labor Pain in Nulli parous Womwn : A Randomized Clinical Trial. J Caring Sciences. 2013; 2 (2) : 123 - 9

5. Winayah, Anis. 2013. Pengaruh Pemberian Musik Klasik Terhadap IntensitasNyeri Persalinan Kala I FaseAktif. Pare: Akbid Pamenang Kediri

6. Kepmenkes RI. 2013. Buku Saku Pelayanan Kesehatan Ibu di Fasilitas Kesehatan Dasar dan Rujukan. WHO

7. JNPK-KR. 2008. Asuhan persalinan Normal. Jaringan Nasional Pelatihan KlinikKesehatan Reproduksi

8. Afroh, F., Mohamad Judha, Sudarti. 2012. Teori Pengukuran Nyeri \&Nyeri Persalinan. Yogyakarta: Nuha Medika

9. Sulistyawati, A. 2013. Asuhan Kebidanan PadaIbu Bersalin. Jakarta: Salemba Medika

10. Shoorab Nj, Zagami SE, Mirzakhani K, Mazlom SR. The Effec of Intravenous Fentanyl on Pain and Duration of the Active Phase of First Stage Labor. OMJ. 2013; 28 (5) : 306 10

11. Murray, S. S. And McKinney, E. S. (2007).Foundations of Maternal Newborn Nursing. 4 ed. Philippines: Saunders

12. Brown, S. T., Douglas, C., \& Flood, L. P. (2001). Women's Evaluation of Intrapartum Non pharmacological Pain Relief Methods Used During Labor. The Journal of Perinatal Education; vol. 10, No. 3 tahun 2001 halaman 1-8. 


\section{STRADA Jurnal Ilmiah Kesehatan}

DOI: $10.30994 /$ sjik.v9i1.281

ISSN: 2252-3847 (print); 2614-350X (online)

Vol.9 No.1. May 2020. Page.248-257

13. Sugiyono. 2012. Metode Penelitian Kuantitatif, Kualitatif, dan R\&D. Bandung: Alfabeta

14. Nasriyah dan Nurul Fania. 2014. Aplikasi Metode Bonapace untuk Nyeri Persalinan di Rumah Bersalin Fatimah Kudus. STIKES muhammadiyah Kudus 2014. Prosiding Media Penelitian dan Pengabdian Masyarakat hal 51 - 59.

15. Bonapace et al.2013.Evaluation of the BonapaceMethod : a spesific educational intervention to reduce pain during childbirth. Journal of Pain Research

16. Mander, R,. 2004. Nyeri Persalinan. Jakarta : EGC

17. Sumarah, dkk. 2009. Perawatan Ibu Bersalin (Asuhan Kebidanan Pada Ibu Bersalin). Jakarta: Fitramaya 